University of Chicago Law School

Chicago Unbound

\title{
Involuntary Confessions: The Allocation of Responsibility between Judge and Jury - A Comment on Stein v. People of the State of New York
}

Bernard D. Meltzer

Follow this and additional works at: https://chicagounbound.uchicago.edu/journal_articles

Part of the Law Commons

\section{Recommended Citation}

Bernard D. Meltzer, Comment, "Involuntary Confessions: The Allocation of Responsibility between Judge and Jury - A Comment on Stein v. People of the State of New York," 21 University of Chicago Law Review 317 (1954).

This Article is brought to you for free and open access by the Faculty Scholarship at Chicago Unbound. It has been accepted for inclusion in Journal Articles by an authorized administrator of Chicago Unbound. For more information, please contact unbound@law.uchicago.edu. 


\title{
THE \\ UNIVERSITY OF CHICAGO LAW REVIEW \\ VOLUME 21 \\ SPRING 1954 \\ NUMBER 3
}

\section{INVOLUNTARY CONFESSIONS: THE ALLOCA. TION OF RESPONSIBILITY BETWEEN JUDGE AND JURY}

\author{
A COMMENT ON STEIN v. PEOPLE OF THE STATE \\ OF NEW YORK
}

BerNard D. MELTZER $\dagger$

\begin{abstract}
"The history of American freedom is, in no small part, the history of procedure."

-Frankfurter, J.*
\end{abstract}

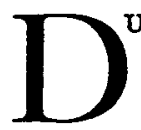

URING THE IAST TWO DECADES, the Supreme Court has given major attention to the task of delineating the ideal of fair criminal procedure and of enforcing that ideal in both the state and federal systems. ${ }^{1}$ One important element in the Court's design has been the elimination of police abuses suggested by "the third degree." The Court had been alerted to the evils reported in the Wickersham Report ${ }^{2}$ and to the brutalities associated with the "police state." In the sphere of federal criminal trials, its response was the development of the prophylactic $M c N a b b$ rule. ${ }^{3}$ In connection with state criminal trials, the Court in 1936 for the first time invoked the Fourteenth Amendment as a protection

$\dagger$ Professor of Law, University of Chicago Law School.

* Malinski v. New York, 324 U.S. 401, 414 (1945).

${ }^{1}$ See, e.g., Rochin v. California, 342 U.S. 165, 169 (1952); Lyons v. Oklahoma, 322 U.S. 596,605 (1944). This development has been part of the significant expansion of the Court's supervision of state criminal proceedings by way of the Fourteenth Amendment. See generally, Boskey and Pickering, Federal Restrictions on State Criminal Procedure, 13 Univ. Chi. L. Rev. 266 (1946); Allen, Due Process and State Criminal Procedures: Another Look, 48 N.W.L. Rev. 16 (1953).

2 IV Reports of National Commission on Law Observance and Enforcement, 1931.

${ }^{3}$ McNabb v. United States, 318 U.S. 332 (1943); Upshaw v. United States, 335 U.S. 410 (1948). In these cases, the Court declared that confessions secured from suspects held in violation of federal prompt-commitment requirements were inadmissible in federal criminal trials, irrespective of whether the reception of such confessions violated the Fifth Amendment. 
against the reception of involuntary confessions ${ }^{4}$ and thereafter progressively broadened the concept of "involuntariness." The Court struggled with the formulation of a rationale for its confession doctrines. ${ }^{6}$ It underscored the significance of these doctrines and increased the risk of noncompliance with them by announcing that the reception of a confession in violation of the Fourteenth Amendment voided a conviction, no matter how persuasive the other evidence of guilt. ${ }^{7}$ Finally, with some wavering both in the formulation and in the application of its doctrine, the Court dealt with the weight to be given to a real or an assumed determination at earlier stages of litigation that a particular confession was "voluntary."

There was, however, one striking omission in the Court's confession business. The Court had not considered the effect of various trial procedures employed to resolve the questions of fact and judgment underlying the voluntariness issue. This was striking because such insights as we have about the trial process suggest that the procedures employed may have an important impact on the effectiveness of the defendant's protection against the use of his involuntary confession.

In Stein v. New York, ${ }^{9}$ the Court, speaking through Mr. Justice Jackson, dealt with this neglected problem. It sustained the constitutionality of a widely prevalent trial procedure under which the voluntariness of a confession is treated like an ultimate issue in the case: The trial judge if he finds that the evidence permits either a determination of voluntariness or one of involuntariness does not resolve the conflicting evidence but admits the confession and instructs the jury to disregard it if it finds the confession to be involuntary. The Court, while sustaining this procedure, filed an unnecessarily broad opinion which challenged the rationale of its earlier confession decisions. There were three angry dissents, ${ }^{10}$ which did

${ }^{4}$ Brown v. Mississippi, 297 U.S. 278 (1936).

${ }^{5}$ Consult McCormick, Some Problems and Developments in the Admissibility of Confessions, 24 Ter. L. Rev. 239 (1946); Ashcraft v. Tennessee, 322 U.S. 143 (1944), esp. Jackson, J., dissenting, p. 156 et seq.; Haley v. Ohio, 332 U.S. 596 (1948); Turner v. Pennsylvania, 338 U.S. 62 (1949), esp. Jackson, J., dissenting in Watts v. Indiana, 338 U.S. 49 (1949), at p. 57.

- See page 348 infra.

${ }^{7}$ See page 344 infra.

${ }^{8}$ See, e.g., Lisenba v. California, 314 U.S. 219, 238 (1941); Watts v. Indiana, 338 U.S. 49, 51-52, 58 (1949); with which cf. Malinski v. New York, 324 U.S. 401, 404 (1945); Haley v. Ohio, 332 U.S. 596, 599, and Burton, J., dissenting, 607, 618-19 (1948). See also Brown v. Allen, 344 U.S. 443, Jackson, J., concurring, 532 (1953).

346 U.S. 156 (1953).

${ }^{10} \mathrm{Mr}$. Justice Black, dissenting, concurred in Mr. Justice Douglas' dissent and also joined Mr. Justice Frankfurter in "protesting the Court's action." Ibid., at 199. Neither Mr. Justice 
not, however, come to grips with the Court's argument as to the validity of the trial procedures involved and which may have obscured the reach of the Court's decision.

Before turning to the problems raised by the Stein case it is useful to examine the variations in trial procedures employed in determining .whether a confession attacked as involuntary may be considered by the jury. The most important differences in these procedures relate to the responsibilities allocated to judge and jury, respectively, in resolving those questions of fact and judgment on which the voluntariness of a confession turns. Although the lines of division are sometimes blurred, courts, in distributing these responsibilities, have developed four basic approaches. ${ }^{.1}$ First is the so-called orthodox view under which the judge alone resolves the question of voluntariness. ${ }^{12}$ Secondly, there is the "New York view" which was involved in the Stein case and which was briefly summarized above. Thirdly, there is the "Massachusetts view" under which the jury

Frankfurter nor Mr. Justice Douglas concurred in Mr. Justice Black's opinion. In this connection it should be observed that Mr. Justice Black alone urged that the admission by a state court of a defendant's confession which implicated a co-defendant denied the co-defendant due process if the defendant did not take the stand, even though the jury was instructed not to consider the confession as evidence of the co-defendant's guilt. Ibid., at 197, $173 \mathrm{n} .17$. Although under such circumstances the reception of the confession, with a limiting instruction, is an established practice [2 Wharton, Criminal Evidence $\S 700$ (11th ed., 1935)], Mr. Justice Black urged that it violated the co-defendant's right to confront, and to crossexamine, the witnesses against him and that this right was guaranteed by the Fourteenth Amendment. The Court might have disposed of this contention on the ground that the jury, if it followed its instructions, would not consider the confession as evidence against the codefendant. But the Court, even though it relied heavily on the assumption of jury-regularity in disposing of other issues in the case, did not mention it in connection with the confrontation issue. Instead, it declared broadly that the right of confrontation guaranteed by the Sixth Amendment does not bind the states by way of the Fourteenth Amendment. It is unlikely that the Court's unnecessarily sweeping announcement will put to rest the question of whether the right of confrontation, which has long been considered a fundamental protection in criminal trials, is protected by the Fourteenth Amendment.

"These variant trial procedures reflect differences and confusions which have generally attended the distribution of functions between judge and jury with respect to the determination of questions of fact on which the admissibility of an item of evidence depends. See generally Maguire and Epstein, Preliminary Questions of Fact in Determining the Admissibility of Evidence, 40 Harv. L. Rev. 392 (1927); cf. Maguire, Evidence: Common Sense and Common Law, c. IX (1947); see also MLorgan, Functions' of Judge and Jury in the Determination of Preliminary Questions of Fact, 43 Harv. L. Rev. 165 (1929); cf. 9 Wigmore, Evidence $\S 2550$ n. 1 ( $3 d$ ed., 1940).

12 This is the procedure followed in England, Rex v. Voisin, [1918] 1 K.B. 531, and in some American states and federal circuits. See page 320 infra. For an extensive collection of American cases, see 3 Wigmore, Evidence $\S 861$ (3d ed., 1940), and 1953 supp.; see also annotations: 85 A.L.R. 870 (1933); 170 A.L.R. 567 (1947). The annotations which neglect some of the distinctions discussed below describe only two types of procedures: (1) where the judge alone resolves the voluntariness question, and (2) where that question is ultimately for the jury. 
under certain circumstances reviews the trial court's determination that a confession is voluntary. Finally, under the fourth view, the trial court is given discretion to follow the orthodox or the Massachusetts view. The ensuing discussion of these variant approaches is designed to be illustrative, and not exhaustive, of the large number of cases involved.

Under the orthodox view the trial judge determines that the confession is voluntary and may be heard and considered by the jury, or that it is involuntary and may not be presented to the jury. Even though he admits the confession and even though he believes that a contrary ruling would have been reasonable, his determination of voluntariness is final and is not re-examined by the jury. ${ }^{13}$ Since, however, the evidence surrounding the making of a confession bears on its credibility, ${ }^{14}$ such evidence may be presented to the jury, not on the issue of the voluntariness or the competency of the confession, but on the issue of its weight.

The issue of credibility and the issue of competency are obviously related because the common-law rationale for excluding involuntary confessions has been their doubtful reliability. These issues are, nevertheless, distinct. A confession, although involuntary, may be extremely credible, for example, when its disclosures are confirmed by independent evidence. Conversely, a confession, although voluntary, may not be credible, for example, when it is the product of hallucination..$^{15}$ Some courts have neglected or obscured the distinction between competency and credibility, ${ }^{16}$ have merged the two issues, and have submitted the competency issue to the jury under the guise of having the jury pass on credibility. This confusion is frequently reflected in opinions which declare that it is the province of the court to resolve questions of admissibility, the province of the jury to determine issues of credibility, but which then approve the trial court's submission of the voluntariness question to the jury, with instructions to consider the confession only if it finds it to be voluntary or not

${ }^{13}$ See, e.g., People v. Fox, 319 Ill. 606, 616-19, 150 N.E. 347, 350-52 (1926); Jackson v. Commonwealth, 193 Va. 664, 673-74, 70 S.E. 2d 322, 327-28 (1952); State v. Seward, 163 Kan. 136, 144-46, 181 P. 2d 478, 484-85 (1947); Wynn v. State, 181 Tenn. 325, 327, 181 S.W. 2d 332 (1944); but cf. Ashcraft v. Tennessee, 322 U.S. 143, 145-47 (1944), which suggests that the Tennessee Supreme Court, while announcing the orthodox rule, failed to notice its violation by the trial court in the Ashcraft case.

${ }^{24} 3$ Wigmore, Evidence $\$ 861$ (3d ed., 1940).

${ }^{25}$ The fear of false, albeit voluntary confessions, is reflected in the requirement that a confession be corroborated. See 7 ibid., at $\$ 2070$. For references to the literature regarding false confessions, see McCormick, op. cit. supra note 5.

${ }^{16}$ See, e.g., Shepherd v. State, 31 Neb. 389, 392-93, 47 N.W. 1118, 1119 (1891); Commonwealth v. Epps, 193 Pa. 512, 516, 44 Atl. 570 (1899); Morris v. State, 39 Tex. Crim. App. 371, 376, 46 S.W. 253, 256 (1898). 
involuntary ${ }_{17}^{17}$ depending on where the burden of persuasion is allocated. ${ }^{18}$

The failure to distinguish competency and credibility and the mistaken notion ${ }^{19}$ that the jury is to have a role in the disposition of all questions of fact arising during a trial ${ }^{20}$ seem to have been partially responsible for the breakdown of the orthodox rule. The greatest deviation from the orthodox view is represented by the procedure, which we have for convenience called "the New York rule" although it is not confined to New York.21

Under the New York rule the jury's role depends in part on whether the evidence permits more than one reasonable conclusion concerning the voluntariness of the challenged confession. If the judge concludes that only a finding of involuntariness is permissible, he excludes the confession, and the question of its competency is, of course, never presented to the jury. ${ }^{22}$ While the judge may thus finally resolve the issue against the prosecution, there is lack of uniformity among jurisdictions ${ }^{23}$ and uncer-

${ }^{17}$ See, e.8., Wood v. State, 72 Okla. Cr. App. 364, 374, 116 P. 2d 728, 733 (1941); State v. Cleveland, 6 N.J. 316, 326, 78 A. 2d 560, 565 (1951).

${ }^{18}$ The cases are divided as to where the burden of going forward and the burden of persuasion on the voluntariness issue should be allocated. See 3 Wigmore, Evidence $\$ 860$ (3d ed., 1940). Wigmore argued that the burden of persuasion should be imposed on the defendant. But his argument ignores the prosecution's superior access to evidence of what occurred during and prior to the defendant's interrogation. This factor alone would seem to justify the allocation of the burden of persuasion on the state. Where the voluntariness issue is submitted to the jury, this allocation would also avoid the possibility of confusion which might rcsult from allocating to the prosecution the burden on the merits, and to the defendant, the burden on the voluntariness issue.

${ }^{12}$ See Thayer, Evidence 185 (1898); 3 Wigmorc, Evidence $\S 861$ (3d cd., 1940), 9 ibid., at $\$ 2550$.

${ }^{20}$ See, e.g., People v. Doran, 246 N.Y. 409, 416-18, 159 N.E. 379, 381-82 (1927); Pcoplc v. Pignatoro, 263 N.Y. 229, 240-41, 188 N.E. 720, 724 (1934) (semble).

${ }^{21}$ See, e.g., Barnes v. State, 217 Ark. 244, 249, 229 S.W. 2d 484, 486 (1950); State v. Winters, 39 Wash. 2d 545, 548, 236 P. 2d 1038, 1041 (1951); State v. Lee, 361 Mo. 168, 233 S.W. 2d 666 (1950). See also State v. Schabert, 218 Minn. 1, 7-9, 15 N.W. 2d 585, 588-89 (1944), which seems to adopt the New York view, but which mistakenly treats that view is identical with the Massachusetts view. See page 323 infra. Downs v. State, $208 \mathrm{Ga} .619,621,68$ S.E. 2d 568, 570 (1952); State v. Hofer, 238 Iowa 820, 828-29, 28 N.W. 2d 475, 480 (1947). Commonwealth v. Epps, $193 \mathrm{~Pa}$. 512, 516, 44 Atl. 570 (1899); Commonwealth v. Turner, $358 \mathrm{~Pa} .350$, 355, 58 A. 2d 61, 64 (1948), rev'd on other grounds, 338 U.S. 62 (1949) (confession received if examination and cross-examination of prosecution witness, apparently outside of the presence of the jury, shows its voluntariness; defendant may thereupon introduce evidence of involuntariness before the jury, and if he does so, voluntariness becomes a question for the jury).

2 See People v. Weiner, 248 N.Y. 118, 122, 161 N.E. 441, 443 (1928); People v. Leyra, 302 N.Y. 353, 364, 98 N.E. 2d 553, 558-59 (1951).

${ }^{23}$ For illustrative cases, which indicate that there is no need to submit the issue to the jury if there is no substantial evidence of involuntariness opposed to the prosecution's evidence of voluntariness, see Williams v. United States, 189 F. 2d 693 (App. D.C., 1951); Iva Ikuko Toquri D'Aquino v. United States, 192 F. 2d 338, 356 (C.A. 9th, 1951); State v. Scott, 209 S.C. 61, 64-65, 38 S.E. 2d 902, 903 (1946); Commonwealth v. Epps, $193 \mathrm{~Pa}$. 512, 516-18, 44 Atl. 570, 571 (1899). Since trial courts, out of an abundance of caution, often submit the 
tainty in particular jurisdiction $\mathrm{s}^{24}$ as to whether the judge may under any circumstances cast the die against the defense. Thus it is not clear whether he must submit the issue of voluntariness to the jury even though the only permissible conclusion is that the confession was voluntary. In such a case, there is no good reason for submitting the issue to the jury since it is an issue of competency and only one answer is reasonable. Nevertheless, in some jurisdictions the established practice seems to be that the judge after admitting the confession always submits the voluntariness issue to the jury. This practice seems to have developed either because of a confusion between competency and credibility ${ }^{25}$ or because of repeated submissions "out of an abundance of caution."

Under the New York procedure, where the judge determines that a "fair question of fact" is presented, the judge, without resolving that question, ${ }^{26}$ submits the issue of voluntariness to the jury. It is said to be improper for the judge to resolve a fair question of fact even though his determination would result in excluding the confession. ${ }^{27}$ This restraint on

issue to the jury even though there is no substantial evidence of involuntariness, judicial announcements that submission is unnecessary under such circumstances are of ten dicta.

The New York Court of Appeals has in one case indicated that where the trial court holds that a confession is voluntary, the voluntariness issue must be submitted to the jury regardless of whether any substantial question of voluntariness was presented. See People v. Pignatoro, 263 N.Y. 229, 240-41, 188 N.E. 720, 724 (1934); but cf. People v. Brasch, 193 N.X. 46, $57-58,85$ N.E. 809,813 (1908) (submission to jury when no substantial issue of voluntariness described as "an abundance of caution"); People v. Doran, 246 N.Y. 409, 416-17, 159 N.E. 379,381 (1927). The Supreme Court in the Stein case interpreted the New York decisions as requiring the submission of the voluntariness issue to the jury in every case where the trial judge admits the confession. 346 U.S. 156, 172 (1953).

24 See note 23 supra.

${ }^{25}$ See People v. Pignatoro, 263 N.Y. 229, 240-41, 188 N.E. 720, 724 (1934).

${ }^{26}$ The court, before admitting the confession, must determine that a finding of voluntariness would be permissible, but it need not, as under the orthodox practice, resolve the conflict in evidence and itself make such a finding. See People v. Doran, 246 N.Y. 409, 416-17, 159 N.E. 379, 381 (1927); People v. Leyra, 302 N.Y. 353, 364, 98 N.E. 2d 553, 559 (1951). Contrast the New York approach to dying declarations under which the competency, as distinguished from the weight, of the declaration need not be submitted to the jury. See People v. Ludkowitz, 266 N.Y. 233, 241, 194 N.E. 688, 691 (1935); Pcople v. Allen, 300 N.Y. 222, 90 N.E. 2d 48 (1949). In some jurisdictions, the procedure for ruling on the admissibility of confessions is also used where the admissibility of dying declarations is involved. See Morgan and Maguire, Cases and Materials on Evidence 623 (3d ed., 1951).

The divergence of procedures in these two situations plainly reflects the failure of the courts to develop and to apply a consistent approach to the problem of distributing functions between judge and jury with respect to the determination of questions of fact on which admissibility depends.

${ }^{27}$ In People v. Doran, 246 N.Y. 409, 418, 159 N.E. 379, 382 (1927), the Court declared: "It may be that a question of fact ... arose as to the voluntary nature of the confession. The jury ... and not the court were the ones to determine the question. . . . For the judge himself to have determined the question of fact and to have excluded the confession altogether would have been going very far indeed toward usurping the functions of a jury, bordering almost on arbitrary action," 
the trial judge's authority has been supported as necessary to protect the jury's prerogative over questions of fact. ${ }^{28}$

A similar argument was properly rejected by the Kentucky Court of Appeals in Bass v. Commonwealth, ${ }^{29}$ which involved the constitutionality of a Kentucky statute enacted in $1942 .{ }^{30}$ The statute in effect substituted the orthodox procedure for the New York procedure which immediately prior to the statute had been followed in Kentucky. In accordance with the statute, the trial judge in the Bass case had resolved the conflict in the evidence, had admitted the confession and had not submitted the voluntariness issue to the jury. The defendant urged that the statutory procedure deprived him of his right to a jury trial guaranteed by the Kentucky Constitution. The Kentucky Court of Appeals rejected that contention on the ground that the earlier and orthodox procedure in Kentucky had conferred on the trial judge final and exclusive responsibility for determining the voluntariness issue. ${ }^{31}$ Accordingly, the court concluded that the statute provided for "a return to, and not a departure from, the ancient mode of trial by jury.."32

The third procedure, the so-called "humane" Massachusetts practice, ${ }^{33}$ may be viewed as a compromise between the orthodox and the New York rules. The judge, as under the orthodox practice, resolves the questions of fact and judgment on which admissibility depends. If he considers a confession involuntary, he excludes it regardless of whether the evidence is conflicting. If, however, he considers the confession voluntary and if the evidence is conflicting, he admits the confession but instructs the jury to disregard it, if it is satisfied that it was not voluntary. ${ }^{34}$

The formal distinction between the New York and Massachusetts pro-

28 Ibid.

29296 Ky. 426, 177 S.W. 2d 386 (1944).

${ }^{30} \mathrm{Ky}$. Rev. Stat. $\$ 422.110$ (1942).

${ }^{31}$ See Hudson v. Conmonwealth, $63 \mathrm{Ky}$. (2 Duv.) 531, 532 (1866); Dugan v. Commonwealth, $102 \mathrm{Ky} .241,251,43$ S.W. 418, 420 (1897); Pearsall v. Commonwealth, $29 \mathrm{Ky}$. Law Rep. 222, 223-24, 92 S.W. 589, 590 (1906).

$296 \mathrm{Ky} .426,431,177$ S.W. 2d 386, 388 (1944).

${ }^{33}$ The "Massachusetts view" has been adopted in other jurisdictions. See, e.g., Read v. People, 122 Colo. 308, 316-17, 221 P. 2d 1070, 1075 (1950); State v. Boswell, 73 R.I. 358, 56 A. 2d 196 (1947); Brunner v. People, 113 Colo. 194, 216, 217, 156 P. 2d 111, 121, 122 (1945) (semble); see also cases referred to in note 35 infra.

${ }^{34}$ See Commonwealth v. Preece, 140 Mass. 276, 277, 5 N.E. 494, 495 (1885); Commonwealth v. Sheppard, 313 Mass. 590, 603-4, 48 N.E. 2d 630, 639 (1943); Commonwealth v. Cullen, 111 Mass. 435 (1873). Later Massachusetts cases have failed to cite Commonwealth $v$. Knapp, 27 Mass. (10 Pick.) 477, 495-96, 20 Am. Dec. 534 (1830), which approved the orthodox view. 
cedures is often blurred in appellate opinions. Under either procedure, the trial court faced with an objection to the admissibility of a confession, must rule on that objection, i.e., must determine whether the jury is to hear the challenged confession. But the controlling question is different under the two procedures. Under the New York procedure admissibility results if the trial judge finds that the evidence presents a substantial question as to voluntariness. But under the Massachusetts procedure admissibility results only if the judge resolves that question in favor of the prosecution. Since courts which require the ultimate submission of the voluntariness issue to the jury refer to the necessity of a judicial determination without specifying its character, it is sometimes difficult to determine which of two procedures is being approved, ${ }^{35}$ or whether a distinction between the two is even recognized.

The Supreme Court in Wilson v. United States ${ }^{36}$ appeared to sanction a fourth variation for federal criminal trials when it said: ${ }^{37}$

These were matters [the circumstances surrounding the making of the defendant's statements] which went to the credibility of what he said of an incriminating character, but as he was not confessing guilt, but the contrary ${ }^{38} \ldots$ they were not of themselves sufficient to require his answers to be excluded on the ground of being involuntary as a matter of law.

When there is a conflict of evidence as to whether a confession is or is not voluntary, if the court decides that it is admissible, the question may be left to the jury with the direction that they should reject the confession if upon the whole evidence they are satisfied it was not the voluntary act of the defendani. (Emphasis supplied.)

The Court's language seems to give the trial court discretion to follow either the orthodox or the Massachusetts view. It was so interpreted by Wigmore, who, in passing, accused the Court of "an unpractical heresy." 39 It should be noted, however, that the Court of Appeals for the Second Circuit, through Judge A. N. Hand, has interpreted the Wilson case as sanctioning only the orthodox procedure, with the role of the jury confined

${ }^{35}$ See, e.g., People v. Fox, 25 Cal. 2d 330, 340, 153 P. 2d 729, 734 (1944) (question of admissibility in first instance "necessarily one of law" but jury must determine whether confession was involuntary); People v. Dabb, 32 Cal. 2d 491, 497, 197 P. 2d 1, 4 (1948); People v. Porter, 99 Cal. App. 2d 506, 509, 222 P. 2d 151, 153 (1950); Gallegos v. State, 152 Neb. 831, 43 N.W. 2d 1 (1950), aff'd 342 U.S. 55 (1951); Patterson v. United States, 183 F. 2d 687, 68090 (C.A. 5th, 1950); United States v. Ruhl, 55 F. Supp. 641, 642, 644-45 (D. Wyo., 1944); State v. Schabert, 218 Minn. 1, 7-9, 15 N.W. 2d 585, 588-89 (1944) (citing New York and Massachusetts cases, indiscriminately); State v. Johnson, 241 Towa 135, 138-39, 39 N.W. $2 d$ 123,125 (1949).

$$
{ }^{36} 162 \text { U.S. } 613 \text { (1896). } \quad{ }^{37} \text { Ibid., at } 624 .
$$

${ }^{38}$ The Court, earlier in the Wilson opinion, had indicated that the defendant's disclosures, although only admissions, would be tested by the rules applicable to confessions. Ibid., at 621 .

393 Wigmore, Evidence $\$ 861$ n. 3 (3d ed., 1940). 
to passing on the probative value, as distinguished from the competency, of the confession..$^{40}$ This interpretation presents several difficulties. It appears to disregard both the Supreme Court's permissive language in the passage quoted above and the fact that the cases cited by the Court ${ }^{41}$ call on the jury to determine the voluntariness, and not merely the weight, of the confession. Furthermore, the fact that the Wilson case sanctions submission of the voluntariness issue to the jury only when a conflict of evidence is involved suggests that the jury is not to be limited to the credibility issue. For in a federal criminal case, the trial court lacks authority to direct a verdict against a defendant on issues involving credibility. Accordingly, the defendant may always raise the issue of the credibility of the confession before the jury regardless of whether the judge believes that there is a conflict in the evidence as to its voluntariness. Conversely, where, as under Wilson, the trial judge has discretion to submit an issue to the jury when he believes a substantial question of fact is raised, the issue to be resolved by the jury would appear to be, not credibility, but competency. In any event, the federal courts, often relying on the Wilson case, have sanctioned a wide variety of practices, ranging from the orthodox $^{42}$ to the New York procedure. ${ }^{43}$ In the latter event, there has usually been no explicit concern for the impact of various procedural alternatives on the extent of the defendant's protection.

The particular procedure employed may, as was suggested earlier, have important consequences on the effectiveness of the defendant's protection against involuntary confessions. It seems likely that this protection is increased by the orthodox procedure under which the trial judge must resolve the conflicting evidence and determine whether a challenged confes-

10 See United States v. Lustig, 163 F. 2d 85, 89 (C.A. 2d, 1947); Accord: Murphy v. United States, 285 Fed. 801, 808 (C.A. 7th, 1923), cert. denied 261 U.S. 617 (1923); Pon Wing Quong v. United States, 111 F. 2d 751, 757 (1940); but cf. United States v. Leviton, 193' F. 2d 848, 852 (C.A. 2d, 1951), cert. denied 343 U.S. 946, reh. denied 343 U.S. 948 (1952).

1 Commonwealth v. Preece, 140 Mass. 276, 277, 5 N.E. 494, 495 (1885); Hardy v. United States, 3 Dist. Col. App. 35 (1893).

12 See Murphy v. United States, 285 Fed. 801, 808 (C.A. 7th, 1925), cert. denied 261 U.S. 617 (1922); Harrold v. Territory of Oklahoma, 169 Fed. 47, 53-54 (C.A. 8th, 1909).

${ }^{43}$ McAfee v. United States, 111 F. 2d 199, 201 (App. D.C., 1940), cert. denied 310 U.S. 643 (1940) (unclear whether voluntariness issue must be submitted to jury even though the determination that the confession was voluntary is beyond reasonable dispute); United States v. Ruhl, 55 F. Supp. 641, 644-45 (D. Wyo., 1944) (semble, see note 35 supra), af'd 148 F. 2d 173 (C.A. 10th, 1945); United States v. Leviton, 193 F. 848, 852 (C.A. 2d, 1951), cert. denied 343 U.S. 946, reh. denied 343 U.S. 948 (1952) (voluntariness issue submitted to jury despite absence of any evidence contradicting denials of coercion by federal officials; no independent determination by trial judge who found conflict on basis of statement by defendant's counsel of what defendant would have said if he had taken the stand; Frank, J., dissented on other grounds). 
sion is voluntary or not involuntary ${ }^{44}$ before it is permitted to go to the jury. Plainly, it is substantially easier to persuade a judge that a fair question of fact or judgment exists than it is to persuade him to accept a particular answer to the question. If the confession is provisionally submitted to the jury because a fair question is involved, it is, of course, doubtful whether the jury will isolate and determine that question. Even if the jury does make this determination and concludes that the confession is involuntary, the defendant will not be benefited thereby unless the jury is able and willing to obey the court's instruction to disregard the confession in passing on the defendant's guilt. The prevailing skepticism regarding the efficacy of such instructions was recently voiced by Mr. Justice Jackson, who said: "The naive assumption that prejudicial effects can be overcome by instructions to the jury, ... all practicing lawyers know to be an unmitigated fiction." 45

Instructions to disregard seem likely to be particularly ineffective in the confession context. The jury in passing on the voluntariness issue under the New York procedure presumably scrutinizes the contents of the confession. ${ }^{46}$ The very act of adjudicating whether the confession should enter the jurors' minds thus serves to impress the confession on their minds. Furthermore, a confession is a dramatic item of evidence, which usually interlocks with other evidence in the case. This increases the difficulty of cutting the proof into bits and pieces and disentangling the confession from the rest of the evidence. These considerations must be brushed aside to accept the New York rule, resting, as it does, on the fragile assumption that the jury in arriving at its ultimate verdict will determine whether a confession is voluntary and then will "disregard" a confession which it finds to be involuntary. It is also relevant in this connection that coerced

${ }^{44}$ The content of the finding which is a predicate for admissibility is related to the allocation of the burden of persuasion. See note 18 supra.

45 See Krulewitch v. United States, 336 U.S. 440, 453 (1949) (concurring opinion relating to limiting instruction concerning use of declarations of co-conspirators); see also Judge Jerome N. Frank's dissent in United States v. Leviton, 193 F. 2d 848, 865 (1951), cert. denied 343 U.S. 946 (1952): "My colleagues admit that 'trial by newspaper' is unfortunate. . . . They rely on the old 'ritualistic admonition' to purge the record. The futility of this sort of exorcism is notorious. . . It is like the Mark Twain story of the little boy who was told to stand in a corner and not to think of a white elephant"; cf. Mr. Justice Cardozo in Shepard v. United States, 290 U.S. 96, 104 (1933); Lehman, J., dissenting in People v. Fisher, 249 N.Y. 419, 431-32, 164 N.E. 336, 339-40 (1928), on the ground that the confession by one co-defendant damaged the other defendant despite the conventional limiting instruction. See also Morgan, Function of Judge and Jury in the Determination of Preliminary Questions of Fact, 43 Harv. L. Rev. $165,168-69$ (1929), and note 64 infra.

${ }^{46}$ In the Stein case, the Court in supporting the (assumed) determination of voluntariness pointed to the detail in, and the general character of, the confession. 346 U.S. 156, 167-68 (1953). See also Commonwealth v. Turner, $358 \mathrm{~Pa}$. 350, 355, 362, $58 \mathrm{~A}$. 2d 61, 63-64, 67 (1948). 
confessions have a positive correlation with crimes which arouse public indignation and public demands for the culprit's scalp. But where public feeling runs high, it is likely that the jury, a miniature public, may well condone the harsh police measures which produce involuntary confessions. ${ }^{47}$ Thus the protection given the defendant by the judicial determination required under the orthodox view, may, under the New York view be diluted when it is most needed.

This is not to suggest that the trial judge is necessarily immune to public pressure. His susceptibility will obviously depend on his tenure and his integrity. Nor is it to suggest that the judge can always prevent his judgment regarding the defendant's guilt from affecting his disposition of the voluntariness issue. But in a jury trial his determination of that issue is separated from any determination of the merits-as a matter of function as well as form. The judge, moreover, generally has the advantage of training, of experience with pat police stories, and of sensitivity to the desire of police and prosecutors to parade a good box score of convictions. ${ }^{48}$

It may be urged that the commitment of our system to jury trial presupposes the acceptance of the assumptions that the jury follows its instructions, that it will make a separate determination of the voluntariness issue, and that it will disregard what it is supposed to disregard. But that commitment generally presupposes that the judge will apply the exclusionary rules before permitting evidence to be submitted to the jury. ${ }^{49}$ Furthermore, as Mr. Justice Frankfurter has said in another context: "Discharge of the jury's responsibility for drawing appropriate conclusions from the testimony [depends] on discharge of the judge's responsibility to give the jury the required guidance by a lucid statement of the relevant legal criteria." issue often fail to measure up to these desirable standards.

State courts have often approved abstract instructions that a confession may be considered if made "freely and voluntarily ... without fear of

${ }^{47}$ Cf. Brown, J., dissenting in Chambers v. State, 136 Fla. 568, 574, 187 So. 156, 158 (1939), rev'd 309 U.S. 227 (1940): "[W] [Wen [law enforcement officers] in their zeal . . go somewhat beyond the bounds fixed by law in their efforts to obtain evidence sufficient to convict those whom they had reason to believe have been guilty of some heinous offense, the public is reluctant to ... condemn them. Indeed, at the time, they are more likely to be praised."

${ }^{48} \mathrm{Cf}$. MacDonald and Hart, The Admissibility of Confessions in Criminal Cases, 25 Can. Bar Rev. 823, 853 (1947).

19 See 9 Wigmore, Ėvidence $\$ 2550$ (3d ed., 1940); Morgan, op. cit. supra note 45, passim, esp. 186-89.

so Bollenbach v. United States, 326 U.S. 607, 612 (1946). This statement was made with respect to instructions regarding the offense charged. 
punishment or hope of reward."51 Such instructions fail to advise the jury of factors, such as the legality of the defendant's detention, the length of his interrogation, his education and sophistication, his opportunity to consult counsel and friends, which the Supreme Court has declared to be relevant to the issue of whether the reception of a confession violates the Fourteenth Amendment. ${ }^{52}$ The Court, nevertheless, has austerely limited, if not abdicated, its responsibility with respect to the adequacy of stateapproved instructions.

In Lyons v. Oklahoma, where the instructions failed to mention either the fact of illegal detention or its relevance, the Court declared:53

The question of how specific an instruction in a state court must be upon an involuntary character of a confession is, as a matter of procedure or practice, solely for the courts of the state. When the state-approved instruction fairly raises the question of whether or not the challenged confession was voluntary ... the requirements of due process, under the Fourteenth Amendment, are satisfied and this court will not require a modification of local practice to meet views that it might have as to the advantages of concreteness. ${ }^{54}$

The general proposition, that instructions which fairly raise the voluntariness issue satisfy the Fourteenth Amendment, is unassailable. But the conclusion that the issue is fairly raised by the instructions which fail to mention criteria declared to be relevant by the Supreme Court is hard to accept.

The Court's deference to local views regarding the adequacy of instructions on the voluntariness issue is consistent with its self-restraint as to instructions with respect to other issues, such as fair compensation, controlled by the Fourteenth Amendment. ${ }^{55}$ But this deference is in sharp contrast with its willingness to impose new criteria of voluntariness on the

51 See, e.g., Ashcraft v. Tennessee, 322 U.S. 143, 146 (1944).

52 See, e.g., Harris v. South Carolina, 338 U.S. 68, 70-71 (1948); Watts v. Indiana, 338 U.S. 49, 52-53 (1948). See also McCormick, op. cit. supra note 5, at 240-45; Allen, The Wolf Case, 45 Ill. L. Rev. 1, 25-29 (1950).

53 322 U.S. 596, 601 (1944).

${ }^{54}$ Cf. Lehman, J., dissenting in People v. Malinski, 292 N.Y. 360, 387-88, 55 N.E. 2d 353,366 (1944): "There can be no fair trial of the issue of whether the confession is voluntary where the jury is not properly informed that the detention was unlawful and they must take that fact into consideration." See also Turner v. Pennsylvania, 338 U.S. 62, 65 (1948), where the Supreme Court, in finding constitutional error in the reception of a confession pointed to the fact that the trial judge in his charge had not only refused to instruct that illegal detention was a relevant factor but also had mentioned the "common sense" justification for such detention.

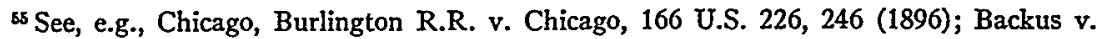
Fort St. Un. Depot Co., 169 U.S. 557, 574-76 (1898); McGovern v. City of New York, 229 U.S. 363, 370-71 (1913). 
states. In any event, the assumption behind the New York procedure that the jury, properly instructed, is qualified to dispose of the voluntariness problem, suggests as a minimum a requiremen $t^{56}$ by way of the Fourteenth Amendment that the instructions contain a "lucid statement of the relevant legal criteria." ${ }^{57}$ Otherwise, the defendant may be deprived of even the theoretical possibility of an informed adjudication of a constitutional issue at the trial level. Although an adjudication may be possible on appeal, many defendants do not avail themselves of their right to appeal. In any event, appellate review, based on the cold printed record ${ }^{58}$ and often limited in scope, is not considered, or designed to be, a substitutc for an informed adjudication at the trial level.

The "humane" Massachusetts procedure ${ }^{59}$ appears to give the defendant greater protection than either the New York or the orthodox procedure. It appears to provide the protection of two independent determinations of voluntariness, by judge and jury, successively. But the double protection may be more apparent than real and the boast of "humaneness" may be only a snippet of provincialism. The prospect of an ultimate jury determination may diminish the judge's sense of responsibility and his care with respect to his initial determination. ${ }^{60}$ In this connection, it should be noted that where the evidence is conflicting, the judge takes final and irrevocable action only if he excludes the confession. If he rcceives it, the use of the confession by the jury still depends theoretically on its finding that it is not involuntary. In a close case, it would not be surprising if the judge resolved doubts in favor of admissibility, thereby avoiding the painful responsibility of an irrevocable decision. Such a judicial attitude would be consistent with the tradition of jury trial on the merits, under which difficult questions are passed on to the jury. ${ }^{61}$ Therc are indications that this tradition operates in connection with the Massachusetts procedure for resolving questions of fact controlling admissibil-

36 It is suggested later in this article that the New York procedure, regardless of the adcquacy of the instructions as to voluntariness, should be held incompatible with the Fourteenth Amendment.

${ }^{37}$ See page 327 supra. The shifting and amorphous quality of the Court's criteria of voluntariness naturally complicates its problem of supervising local instructions. But it is doubtful that this problem poses greater difficulties than the Court's direct intervention with respect to the criteria themselves.

s8 Cf. Stein v. New York, 346 U.S. 156, 197 (1953).

"See Commonwealth v. Preece, 140 Mass. 276, 277, 5 N.E. 494, 495 (1885).

0 See Morgan, op. cit. supra note 45, at 176; McCormick, op. cit. supra note 5, at 251; but cf. Jackson, J., dissenting in Ashcraft v. Tennessee, 322 U.S. 143, 172 (1944).

${ }^{81}$ Cf. 1 Holmes-Pollock Letters 85-86 (1941). 
ity. ${ }^{62}$ To the extent that it does, the Massachusetts procedure, instead of protecting the defendant with two independent determinations of the voluntariness issue, will, in actual operation, approach the New York procedure and will deprive the defendant of even a single clean-cut determination.

The effectiveness of the defendant's protection against coerced confessions is dependent not only upon the judge-jury allocation, but also upon the rules regulating the conduct of the preliminary hearing on the voluntariness issue. Of special significance are rules relating to (1) the defendant's right to have the jury excluded, (2) his right to call other witnesses and to take the stand before the jury is permitted to hear the confession, and (3) the extent to which the defendant by testifying on the voluntariness issue exposes himself to cross-examination and impeachment.

Generally courts, regardless of the established pattern of judge-jury allocation, have declared that the exclusion of the jury during the preliminary hearing is, on the defendant's request, required or is at least the better practice. ${ }^{63}$ This practice is, of course, designed to protect the defendant against the jury's learning of the contents or the existence of a confession which is later held to be inadmissible. The practice of excluding

${ }^{62}$ Cf., e.g., Indian Fred v. State, 36 Ariz. 48, 58-59, 282 Pac. 930, 934 (1929); Read v. People, 122 Colo. 308, 316-19, 221 P. 2d 1070, 1075-76 (1950), where the Supreme Court of Colorado suggested that the trial judge had failed to discharge his duty of making an independent determination of voluntariness because he was relying on a subsequent jury determination of that issue.

In the Read case the Court went on to say: "We now say, and reiterate, with the hope of finality, that henceforth to determine the question of admissibility of written confessions, the same as all other proffered evidence, is solely the duty of the trial court. ... However,... where there is a conflict in the evidence as to the voluntariness of a confession, it is proper that the court instruct the jury that if they do not believe the confession was made freely and voluntarily, they are at liberly to disregard it in arriving at their verdict." Ibid., at 1076 (emphasis added). It is unlikely that this obscure announcement will set the question at rest in Colorado: Is the judge alone to determine the issue of voluntariness? If so, why instruct the jury on that issue? And what does it mean to say the jury is at liberly to disregard a confession which it finds involuntary? Since the jury is the final arbiter of credibility, it is at liberty to disregard all confessions whether voluntary or otherwise.

${ }^{63}$ Sec, e.g., State v. Green, 221 La. 713, 730, 60 S. 2d 208, 213 (1952) (orthodox rule as to juclge-jury allocation); State v. Schabert, 218 Minn. 2, 8, 15 N.W. 2d 585, 588 (1944) (New York rule as to judge-jury allocation; see note 21 supra); People v. Thomlison, 400 Mll. 555, 81 N.E. 2d 434 (1948); State v. Plude, 230 Iowa 1, 6, 296 N.W. 732, 734 (1941).

Contra: State v. Kelly, 28 Ore. 225, 227, 42 Pac. 217, 218 (1895) (not clear, whether orthodox or Massachusetts rule regarding judge-jury allocation followed); Ramirez v. State, 55 Ariz. 441, 103 P. 2d 459 (1940) (unclear whether Massachusetts or New York procedure as to judge-jury allocation followed; apparently Massachusetts); People v. Gonzales, 24 Cal. 2d $870,876,151$ P. 2d 251, 254-55 (1944) (Massachusetts view as to judge-jury); People v. Randazzio, 194 N.Y. 147, 87 N.E. 112 (1909); cf. People v. Farmer, 194 N.Y. 251, 87 N.E. 457 (1909).

In the Randazzio case, the New York Court of Appeals declared not only that the presence of the jury would be proper but also that its exclusion from the preliminary hearing would be error. It is difficult to understand why this should be so. 
the jury is not without its cost. If the confession is admitted, the prior exclusion of the jury will generally prolong the trial. The evidence relating to voluntariness, since it also bears on the credibility of the confession, may have to be repeated to the jury. This is true regardless of which rule as to judge-jury allocation prevails. And under the New York and Massachusetts rules, the evidence may have to be repeated so that the jury may pass on the competency of the confession as well as its weight. Nevertheless, the importance of protecting the defendant against the hazards resulting from the jury's knowledge of an "inadmissible" confession seems to override the considerations of trial economy. In this connection, it should again be observed that there is considerable skepticism regarding the efficacy of an instruction to the jury to disregard a confession brought to its attention during the preliminary hearing even though the confession is subsequently excluded by the trial judge..$^{64}$

The exclusion of the jury where the New York rule as to judge-jury allocation is used is not entirely consistent with the presuppositions of that rule. That rule presupposes that even though the jury hears a confession which is admitted after a preliminary hearing, the jury can and will apply the standards of voluntariness, and if it finds the confession to be involuntary, reject it, i.e., decide the case as if it had not heard the confession. If the jury is considered able to disregard a confession which the court admitted, it should also be able to disregard a confession which is referred to in a preliminary hearing and which is later excluded as involuntary by the court. Accordingly, in view of the assumption behind the New York procedure, there is no logical justification for the prolongation of the trial which results from the exclusion of the jury during the preliminary hearing. ${ }^{65}$ The practice of excluding the jury in jurisdictions following the New York rule presumably reflects doubts as to the reality of the assumption underlying that rule.

Even where the absence of the jury during the preliminary hearing is said to be the proper procedure, its presence is sometimes dismissed as nonprejudicial error if the confession is ultimately admitted by the trial judge. ${ }^{66}$ This approach may give the defendant greater protection than an

see the eloquent statements in Hall v. State, $65 \mathrm{Ga} .36,39$ (1880); Harrold v. Territory of Oklahoma, 169 Fed. 47, 53-54 (1909); but cf. Holmes, J., in Holt v. United States, 218 U.S. 245,249 (1910).

${ }^{85}$ Cf. Ramirez v. State, 55 Ariz. 441, 450, 103 P. 2d 459, 462 (1940). "There was no error in the court's refusal to hear evidence as to the voluntary character of the confession in the absence of the jury, because ... the final decision of that question may be left to that body."

${ }^{86}$ See Ramsey v. United States, 33 F. $2 d 699$ (C.A. 8th, 1929); but cf. Holt v. United States, 218 U.S. 245, 249 (1910); State v. Vey, 21 S.D. 612, 614, 114 N.W. 719, 720 (1908); State v. Green, $221 \mathrm{La} .713,730,60 \mathrm{~S} .2 \mathrm{~d} 208,213$ (1952) (no reversible error if a confession ultimately held to be admissible is received in the presence of the jury provided the defendant "is given 
instruction to the jury to disregard a confession held to be inadmissible, but it involves the danger that a trial judge who has conducted a hearing in the presence of the jury will resolve doubts in favor of voluntariness in order to avoid a mistrial or reversal.

Additional disadvantages from the jury's presence accrue to the defendant because of the rules relating to the scope of rross-examination, and to the impeachment of the defendant who has testified during the preliminary hearing. Where, as is generally the case, the defendant's right to be heard during the preliminary hearing is recognized, ${ }^{67}$ the defendant's fear of cross-examination on the merits may discourage him from testifying. The extent to which the defendant who takes the stand waives his privilege against self-incrimination is frequently not clear. ${ }^{68}$ Even if the waiver should be confined to matters bearing on coercion, it is arguable that questions going to the truth of the confession, i.e., the merits, are proper. It is not a large step from the premise that involuntary confessions tend to be unreliable to the premise that reliable confessions tend to be voluntary. ${ }^{69}$ The acceptance of the second premise would make crossexamination on the merits relevant to the coercion issue. It is true that, even though the relevancy argument is conceded, the defendant might be protected against such cross-examination on the ground that he should

the right to traverse the State's evidence outside the presence of the jury"); contra: English v. State, 206 Miss. 170, 39 So. 2d 876 (1949). Failure to exclude the jury was held in the English case to be a violation of the defendant's constitutional right to be heard and prejudicial error even though judge's reception of confession as voluntary might have been proper. The court, nevertheless, indicated that failure to hold a preliminary hearing might in some cases not constitute reversible error.

${ }^{67}$ State v. Lanthier, $201 \mathrm{La} .843$, 10 S. 2d 638 (1942) (orthodox view); New York v. Fox, 121 N.Y. 449, 453-54, 24 N.E. 923, 924 (1890); Commonwealth v. Culver, 126 Mass. 464 (1879).

${ }^{68}$ See People v. Trybus, 219 N.Y. 18, 24-25, 113 N.E. 538, 540 (1916). Defendánt who testifies as to voluntariness may, in the discretion of the trial court, be cross-examined on the merits. But cf. State v. Thomas, 208 La. 548, 23 S. 2d 212 (1945); see generally, Morgan and Maguire, Cases on Evidence 466 (3d ed., 1951).

69 'The step was taken in Stein v. New York, 346 U.S. 156, 175 (1953). In this connection, one caveat must be noted. Where the police prior to interrogation have developed a clear-cut theory of a suspect's guilt, strong pressures for coercing a confirmatory confession may be operative. A weak suspect, regardless of his guilt or innocence, may succumb to coercion, in part because of the apparently strong case against him.

The Supreme Court's approach gets some support from an unusual English case, Rex v. Hammon, [1941] 3 All. E. R. 318, noted 5 Mod. L. Rev. 236 (1942). In the Hammon case, during the preliminary hearing the accused testified on direct examination that rough treatment induced his confession and on cross-examination answered "yes" to the question of whether his confession was true. His answer was later read to the jury, which returned a verdict of guilty. The Court of Criminal Appeal, while recognizing some doubt as to the propriety of the question, concluded that it was proper because the truth of the confession went to the issue of whether the defendant had been ill-used. 
not be required to yield his rights against self-incrimination in order to vindicate his rights against coerced confessions. ${ }^{70}$ Although this is a persuasive argument, the prevailing uncertainty as to the defendant's position, together with the judicial alacrity to narrow the privilege by waiver doctrines, will often operate to keep the defendant from taking the stand in the presence of the jury. ${ }^{71}$ This factor, it may be noted, will operate not merely during the preliminary hearing but during all stages of the trial where the voluntariness issue is being litigated.

One qualification on the foregoing argument should be noted. If the defendant, even with the jury excluded, should make admissions during a proper cross-examination, they would presumably be receivable against him in the trial before the jury. Accordingly, the scope of the crossexamination may appear to be a more important factor in the defendant's decision to testify than the presence of the jury. In practice, however, defendants appear more willing to take the stand when the jury is absent, ${ }^{72}$ perhaps because they do not thereby highlight their subsequent silence on the merits.

The defendant is also deterred from testifying on the voluntariness issue when the jury is present because of his vulnerability to impeachment by proof of his prior convictions and by related techniques, whose damaging effects are familiar. ${ }^{73}$ The fear of such impeachment, as well as the fear of extensive cross-examination, in the jury's presence, may induce the defendant to be silent during the preliminary hearing and may result in the judge making his determination on the basis of a partial and a prosecution-oriented view of the evidence.

The Supreme Court in United States v. Carignan ${ }^{74}$ recently recognized the defendant's right to have the jury excluded during the preliminary

70 Cf. State v. Thomas, 208 La. 548, 555, 23 S. 2d 212, 214 (1945): "Thus it would be a simple matter for an unconscionable person to extort from the accused while alone a confession (through promises, threats or violence) and thereafter falsely testify that it was given freely and voluntarily. Whereupon the accused would be compelled to take the stand to contradict the witness, thereby subjecting himself to cross-examination on the whole case, or he would have to let the extorted confession go unchallenged. Either of these alternatives would do violence at least to the spirit of the Constitution."

"Thus the defendant frequently will take the stand during the preliminary hearing outside the presence of the jury but not when the voluntariness issue is retried before the jury. See, e.g., Carignan v. United States, discussed page 334 infra; Lewis v. United States, 74 F. 2d 173 (C.A. 9th, 1934); McNabb v. United States, 123 F. 2d 848, 852 (C.A. 6th, 1941), rev'd on other grounds 318 U.S. 332 (1942).

I2 See cases note 71. supra.

"See Meltzer, Required Records, the McCarran Act and the Privilege Against SelfIncrimination, 18 Univ. Chi. L. Rev. 687, 691 (1951).

74342 U.S. 36 (1951). 
hearing, at least while the defendant is testifying on the voluntariness issue. The Court's treatment of the procedural problems in the Carignan case justifies a brief digression because its separation of interrelated issues seems artificial and the scope of its ruling on the requirement that the jury be excluded is not entirely clear.

In the Carignan case, the trial judge, upon being informed by the prosecutor that the confession was voluntary, in the presence of the jury received testimony from a United States Marshal as to the circumstances under which the confession was taken. ${ }^{75}$ The defendant's lawyer, after cross-examining the Marshal, requested that the jury be excused so that defendant could be examined as to the circumstances surrounding his statement. ${ }^{76}$ The trial court denied this request, stating, "I have heard enough evidence on this matter." 77 The confession was thereupon admitted over objection, ${ }^{78}$ and the defendant did not thereafter take the stand. In his opinion, the trial judge gave the following explanation of his reasons for having adopted the foregoing procedure: $:^{79}$

Upon being assured by the U.S. Attorney that the confession was freely and voluntarily made, the Court permitted the witness Herring to testify in the presence of the jury as to the circumstances under which it was obtained. Being of the opinion that the confession was voluntarily made, the Court refused to hear the defendant's version out of the presence of the jury and this refusal is now urged as error. ... If any error was committed, it was committed not in refusing to hear the defendant in connection with a preliminary inquiry conducted in the absence of the jury, but in admitting the confession into evidence in connection with the witness Herring's testimony. Once the Court became convinced that the confession had been freely and voluntarily made, the testimony of the defendant, if received preliminarily, could have accomplished no more than to present a conflict in testimony, thus requiring the submission of the question to the jury. The defendant was not ... denied the opportunity to tell his story to the jury. [Defendant] having declined to do so, it became the duty of the Court to pass on its admissibility. (Emphasis added.)

It is not clear whether the trial judge considered the New York or the Massachusetts rule as to judge-jury allocation appropriate. The judge's statement that he was convinced of the voluntariness of the confession suggests that he made the finding required by the Massachusetts rule. On the other hand, his willingness to make that finding without hearing from the defendant and his intimation that a conflict in the evidence would require the submission of the confession to the jury, regardless of how the judge would himself have resolved that conflict, points to the New York rule.

\footnotetext{
${ }^{75}$ 'Transcript of Record in Supremc Court, Oct. Term 1951, No. 5, pp. 21851.

70 Ibid., at 232. $\quad 77$ Ibicl. $\quad 78$ Ibicl., at $233 . \quad 79$ Mbid., at 40.
} 
If a federal trial judge is permitted to employ the New York procedure, there is, as already indicated, considerable force to the trial judge's argument that the defendant was not harmed by the refusal to exclude the jury. The proper judge-jury allocation would thus appear to be a question which had to be faced in order to assess the effect of any procedural irregularity below. A clarification of the judge-jury problem would, moreover, have been desirable in view of the differences and confusions which surround this problem in the federal courts. ${ }^{80}$ Although the government confessed error because of the failure to hear the defendant in the absence of the jury and although it referred to conflicting federal cases on the problem of judge-jury allocation, ${ }^{81}$ the government did not deal with that problem. The Court, although accepting the confession of error, ${ }^{82}$ was equally reserved on this issue.

The Court also declined to deal with a related problem explicitly raised by the defense: whether the failure to submit the voluntariness issue to the jury had been error. ${ }^{83}$ In view of the possible relationship of that question to the proper procedure during the preliminary hearing, ${ }^{84}$ the Court's breakdown of the issues seems particularly precious. In any event, the net effect of its reserve is to raise some doubt about the present status of the declaration in the Wilson case that submission of the voluntariness question to the jury is discretionary. ${ }^{85}$ In view of that doubt, a trial court

${ }^{80}$ See notes 42 and 43 supra.

81 Brief for the United States at 19.

82 The confession of error and its acceptance by the Court is a repudiation of Holt $v$. United States, 218 U.S 245 (1910). In that case, the district attorney during the preliminary hearing in the presence of the jury spoke of the admissibility of confessions. The trial court subsequently excluded any evidence of the defendant's statements on the ground that his statements, if any, were not freely made. The Supreme Court, through Holmes, J., rejected the claim of error based on the trial court's failure to exclude the jury. The Court, although recognizing that "the more conservative course is to exclude the jury during consideration of the admissibility of the confessions ..." (ibid., at 249), concluded that the defendant was adequately protected by the judge's instructions that counsel's remarks should be disregarded.

The Holt case differed from the Carignan case in that only the existence of a confession and not its contents was brought to the jury's attention. That difference is not, however, a satisfactory basis for a distinction between the two cases. Where a jury present during a preliminary hearing has been informed of the existence of a confession which is excluded, the defendant's claim of prejudice based solely on the jury's presence is more persuasive than in the situation where the contents of a confession are disclosed in a preliminary hearing before the jury but where the hearing results in a determination of admissibility.

${ }^{83}$ United States v. Carignan, 342 U.S. 36, 38-39 (1951).

$\mathbf{8 4}$ If, where there is conflicting evidence as to voluntariness, the trial judge is not to resolve the conflict, but to submit the voluntariness question to the jury, it is arguable that he can dispense with the defendant's testimony entirely since it would at best create only a conflict. See page 336 infra. If, as under the Massachusetts procedure, the judge must himself resolve the conflict, even though he subsequently submits the question to the jury, this argument cannot, of course, be made.

${ }^{85}$ See page 324 supra. 
anxious to avoid reversal might consider it prudent to submit the issue of voluntariness to the jury. Thus the Supreme Court may, for the purpose of trial administration, have answered the question which it explicitly reserved. ${ }^{86}$

The Court created additional uncertainty by narrowing the government's confession of error without indicating whether it was doing so deliberately. The Government had confessed error on the ground that "the better practice when the admissibility of a confession offered in evidence is objected to by the defense, is for the trial judge to excuse the jury and hold a hearing as to facts bearing on admissibility." 87 This concession went beyond the objection made by the defense at the trial since the government called for the exclusion of the jury from the beginning of the preliminary hearing and not merely during the defendant's testimony. The Court, however, dealt only with the point involved below and announced only that the defendant was entitled to have the jury excluded when he was testifying. ${ }^{88}$ Although the absence of any explicit reference to the narrowing of the government's position suggests that the Court's action was inadvertent, it could be explained on the ground that the Court was seeking only to protect the defendant from cross-examination or perhaps impeachment, in the jury's presence. ${ }^{89}$

Regardless of the prevailing rules as to the propriety of the jury's presence and as to judge-jury allocation, the defendant's right to testify and to call other witnesses during the preliminary hearing is generally recognized. ${ }^{90}$ Where the New York view as to judge-jury allocation prevails, the denial of the defendant's right to testify during the preliminary hearing can, however, logically be dismissed as not being prejudicial. Since under this view the existence of a fair question of fact regarding voluntariness is a basis for provisional admissibility, once the prosecution introduces credible evidence of voluntariness, the confession should go to the jury regardless of the nature of the defendant's own testimony. The defendant's word opposed to that of the police would produce the fair question. Accordingly, a few cases, although they are not always clear, have indicated that in such a situation the refusal to hear the defendant,

${ }^{88}$ It has not been possible to test this point by the subsequent history of the Carignan case. A letter from the trial judge, the Hon. George W. Folta, dated October 17, 1953, indicates that the case has not been, and probably will not be, retried.

87 Brief for United States at 18.

88342 U.S. 36, 38 (1951).

"See page 333 supra.

${ }^{90}$ Sec note 67 supra. 
if error, is not prejudicial error. ${ }^{91}$ Reversal because of such refusal could rest on the ground that the defendant had been denied a fair hearing and that reversal should therefore be automatic without speculation as to what the record would have been had the defendant's rights been respected. ${ }^{92}$ Reversal on this basis may seem doctrinaire since the defendant's testimony during a new trial would presumably not affect the admissibility of the confession.

Similarly, the refusal during the preliminary hearing to hear other witnesses offered by the defendant could under the New York procedure usually be dismissed as harmless error. One can imagine situations where this would not be true. Where the defendant could have elicited disinterested testimony of such force as to require disbelief of the police testimony, rejecting his offer of proof would appear to be prejudicial. If, for example, he could have elicited proof that he had no bruises before arrest, but that he had bruises immediately after interrogation and that the bruises were not inflicted by his fellow-prisoners or by strangers and were not self-inflicted, rejection of his proof at the preliminary stage would involve prejudicial error. If the judge had heard such proof, presumably he would have excluded the confession. But even under such circumstances, if the assumptions that the jury will, in accordance with the judge's instructions, determine the voluntariness issue and reject an involuntary confession are maintained, and if the evidence, apart from the confession, warranted a conviction, a formal argument could be made that no prejudicial error was involved. These assumptions mean that the defendant was not harmed by the failure to reject the confession at the threshold. Although the cases generally do not appear explicitly to have pushed these assumptions so far, it should be observed that the procedures in some

${ }^{91}$ See State v. Hofer, 238 Iowa $820,830,28$ N.W. 2d 475, 480 (1947); see also quotation from trial court's opinion in United States v. Carignan, page 334 supra. Cf. Tyler v. United States, 193 F. 2d 24, 28 (App. D.C., 1951) (defendant not harmed by failure to hold a preliminary hearing since the evidence which was introduced developed a conflict as to whether the confession was voluntary); State v. Thomas, 250 Mo. 189, 207, 209, 157 S.W. 330, 336 (1913) (error in denying defendant opportunity to call other witnesses and to testify during preliminary hearing harmless since court later received this evidence and since evidence did not support claim of involuntariness).

It is significant that Utah, when it followed the New York view as to judge-jury allocation during the preliminary hearing, confined the defendant to cross-examination of the prosecution witnesses. State v. Wells, 35 Utah 400, 100 P. 681 (1909). When the Utah Supreme Court repudiated the New York view and adopted the orthodox view, it also recognized the defendant's right to present his case as to involuntariness before the confession is received. See State v. Crank, 105 Utah 332, 353, 373-74, 142 P. 2d 178, 187-88, 196-97 (1943).

${ }^{92}$ See Hilliard, J., dissenting in Cahill v. People, 111 Colo. 29, 39, 137 P. 2d 673, 678 (1943); cf. People v. Fox, 121 N.Y. 449, 453-54, 24 N.E. 923, 924 (1890); English v. State, 206 Miss. 170,39 S. $2 d 876$ (1949). 
states in effect do so. Thus the practice in Pennsylvania is for the trial judge to admit a confession if the prosecution's witnesses, who are examined and subject to cross-examination in the absence of the jury, show it to be voluntary. Thereafter, the defendant may introduce his evidence as to involuntariness to the jury, which will be instructed to reject the confession if it finds it to be involuntary.$^{93}$ Under this practice a confession may be heard by the jury even though the defendant's evidence might have persuaded the judge that a finding of voluntariness would have been unreasonable.

It may be useful at this point to summarize somewhat dogmatically the suggestions as to the proper procedure for determining the admissibility of a confession which are implicit in the foregoing discussion:

(1) The orthodox rule as to judge-jury allocation seems necessary in order to insure the defendant a clean-cut adjudication of the voluntariness issue and in order to prevent the jury from merging that issue into the issue of guilt.

(2) The preliminary hearing should be held outside of the presence of a jury. The exclusion of the jury (a) protects the defendant from the prejudice which might result from references in the jury's presence to a confession subsequently held inadmissible; (b) it also protects the defendant from the possibility that a trial judge will hold a confession admissible in order to avoid the reversal or mistrial which might result from a hearing in the jury's presence coupled with a finding of inadmissibility; and (c) it dilutes deterrents against the defendant's testifying on the voluntariness issue.

(3) During the hearing the defendant should have the right to crossexamine the prosecution's witnesses, to present his own witnesses, and to take the stand himself.

The foregoing suggestions have long been urged by Wigmore and other distinguished commentators. ${ }^{94}$

(4) Finally, the defendant should not become vulnerable to crossexamination on the merits merely because he testifies on the voluntariness issue. Otherwise, the defendant in order to protect himself against the use of his coerced confession would be required to waive his privilege against

${ }^{93}$ See Commonwealth v. Turner, 358 Pa. 350, 355, 58 A. 2d 61, 64 (1948).

243 Wigmore, Evidence $\$ 861$ (3d ed., 1940). See also, e.g., Morgan, op. cit. supra note 45 , at 169,177; Rules 8 and 63(b) of the Uniform Rule of Evidence (Nat'l Conf: of Comm'rs of Unif. State Laws, 1953) require the trial judge, if requested, to hear evidence as to admissibility of a confession outside the presence of the jury and also to determine that the confession was not involuntary. Cf. Rules 11, 505, Model Code of Evidence (A.L.I., 1942), which give the trial judge discretion to hold the preliminary hearing in or outside the presence of the jury. 
self-incrimination. However one resolves the old debate about the utility of the privilege; so long as the privilege is recognized, the case for narrowing it with respect to a defendant attacking a confession as coerced is not particularly appealing.

(5) The burden of persuasion on the issue of voluntariness should rest on the state because of the state's superior access to the relevant evidence.

Before turning to the Stein case, it is worth noting that the law of New York where the Stein case was tried, rejects each one of these protective rules except the rule as to the burden of persuasion. ${ }^{95}$ The New York rules, accordingly, operate harshly against a defendant who challenges the voluntariness of a confession.

\section{II}

Although earlier confession cases decided by the Supreme Court had arisen out of trials in which the New York rule as to judge-jury allocation had been employed, ${ }^{96}$ the difficulties inherent in that procedure were for the first time brought to the surface and measured against the requirements of the Fourteenth Amendment in the Stein case. ${ }^{97}$ Under the Court's formulation of the issues, a hypothetical question became the decisive one: Would a separate determination by the jury, if one had been made, that a confession was "voluntary" be consistent with the Fourteenth Amendment? If so, a conviction of guilt would not be invalidated because of the failure of a general verdict of guilty to disclose what determination, if any, the jury had made on the issue, or what use, if any, the jury had made of the confession in arriving at a verdict of guilt. Since the majority would have sustained a separate finding of voluntariness in the Stein case, it refused to reverse the conviction.

The dissenters, Mr. Justice Black, Mr. Justice Frankfurter, and Mr. Justice Douglas, would have declared an explicit finding of voluntariness irreconcilable with the Fourteenth Amendment and would have reversed on that ground. If this were the only difference within the Court, the Stein case would be merely another reminder that different men apply the amorphous standards of voluntariness differently. The dissenters, however, charged not only that constitutional standards of judgment had been misapplied but also that such standards had been overturned. $\mathrm{Mr}$. Justice Frankfurter, for example, declared: ${ }^{98}$

${ }^{25}$ See People v, Doran, 246 N.Y. 409, 416, 15 N.E. 379, 381 (1927).

* See, e.g., Ashcraft y. Tennessee, 322 U.S. 143 (1944); Malinski v. New York, 324 U,S, 401, 435-37 (1945); Tumer v. Pennsylvania, 338 U.S. 62 (1949).

"7 346 U.S. 156 (1953).

98 Ibid., at 200. 
I regret that the Court reaches another conclusion on the record, though I respect a conscientious interpretation of the record differing from mine.

But the Court goes beyond a mere evaluation of the facts of this record. It makes a needlessly broad ruling of law which overturns what I had assumed was a settled principle of constitutional law. It does so sua sponte. The question was not raised and not argued and has emerged for the first time in the Court's opinion. ${ }^{99}$ Unless I am mistaken about the reach of the Court's opinion, and I profoundly hope that $I$ am, the Court now holds that a criminal conviction sustained by the highest court of a State, and more especially one involving a sentence of death, is not to be reversed for a new trial, even though there entered into the conviction a coerced confession which in and of itself disregards the prohibition of the Due Process Clause of the Fourteenth Amendment. The Court now holds that it is not enough for a defendant to establish in this Court that he was deprived of a protection which the Constitution of the United States affords him; he must also prove that if the evidence unconstitutionally admitted were excised there would not be enough left to authorize the jury to find guilt.

An impressive body of opinion, never questioned by any decision or expression of this Court, has established a contrary principle.

The controversy as to voluntariness was compounded of familiar ingredients: arrest, detention without the prompt arraignment before a magistrate required by state statutes, intermittent but lengthy interrogation by "relays" of police, confessions, charges of police brutality by the accused, denials and claims of good treatment by the police. More concretely, evidence concerning the more important of the two confessions involved, the one made by defendant Cooper, was, in substance, as follows: ${ }^{100}$ Cooper, among others, had been suspected of complicity in a felony-murder, which had occurred during a hold-up of a Reader's Digest truck. Cooper was arrested and, in violation of New York statutes, was held incommunicado for about three days without being arraigned before a magistrate. He was interrogated for three or four hours on the first day and for about eight hours on the second day. After the eight-hour interrogation, at about 6 P.M., or 32 hours after his detention, he began to discuss confessing. Before doing so, he bargained for the release of his father, who had been arrested with him, and for a commitment that his

99 The Court's grant of certiorari was "limited to the question as to the admissibility of the confessions." Stein v. New York, 344 U.S. 815 (1952). Construed narrowly, this limited grant would cover only the question of whether the confessions involved were involuntary and not the question also considered by the Court, namely, whether the New York procedure for resolving the voluntariness issue is contrary to the Fourteenth Amendment. But the close connection between these two questions is plain, and it is fairly arguable that "the admissibility of the confessions" covers the procedure by which the confessions were admitted. Defendants' counsel did not, however, argue this procedural question, and it is unfortunate that this question was resolved without the benefit of argument. It should be noted that even if the Court went beyond the terms of its grant of certiorari, its action in this regard did not adversely affect the parties to the cases before it.

${ }^{100}$ The summary of the cvidence is based on the Court's opinion and not the record. 
brother, who also had been arrested and who was in violation of parole, would not be "molested." Cooper, after receiving assurances which he considered satisfactory, at about 10 P.M., or about 36 hours after his detention, made a full oral confession. He made this confession to the parole agents with whom he had bargained, rather than to the police whom he later accused of brutality. Thereupon, the confession was typed and corrected and signed at 1:30 or 2 A.M. of the next morning, or about 40 hours after his detention. The confession was 12 pages long, in great detail, and dovetailed with both the independent evidence and another confession made under somewhat similar circumstances by Stein, the second of the three co-defendants, who confessed after being told of Cooper's prior confession. Wissner, the remaining co-defendant, did not confess.

During the preliminary hearing as to voluntariness, which was held in the presence of the jury, all three defendants charged the police with physical violence, but they did not take the stand to support this charge, apparently in part because they feared that they would have become subject to cross-examination on the merits and to impeachment by proof of their impressive criminal records. The police denied any violence or threats and also testified in effect that the defendants were given good treatment. The chief support for the charge of violence consisted of the testimony of the prison doctor, who had examined the three defendants the day after their arraignment. At the time of this examination Cooper had been in custody for four days; Stein, a co-defendant, for 3 days and about 7 hours; and Wissner, the other co-defendant, for about 2 days. The doctor testified that all three defendants showed bruises and injuries which could have been the result of third degree methods. Wissner, the one defendant who did not confess, had the most serious injuries, including a broken rib. ${ }^{101}$ There was also medical testimony that the injuries could have been sustained prior to arrest.

The confessions were provisionally admitted by the trial judge. Apart from the confessions, there was other evidence which the Supreme Court found to be ample to sustain a verdict of guilt. ${ }^{102}$ The jury returned a gen-

${ }^{101}$ The fact that the most recalcitrant suspect had the most serious injuries naturally suggests that the police stepped up their pressure when the suspects failed to break. That fact and the fact that all of the defendants showed some bruises support the claim that all of them were subject to rough treatment. The Court did not explicitly deal with this argument. Instead, it sought to explain the greater seriousness of Wissner's injuries by referring to hearsay testimony, not objected to, that Wissner had been undergoing medical treatment, not further specified, before his arrest. See 346 U.S. 156, 170 (1953). For a more skeptical treatment of police denials inconsistent with evidence of only one defendant's bruises, see State v. Johnson, 241 Iowa 135, 139, 39 N.W. 2d 123, 125 (1949); People v. Valletutti, 297 N.Y. 226, 78 N.E. 2d 485 (1948).

102 This evidence is summarized, 346 U.S. 156, 160-66 (1953). 
eral verdict of guilty of murder. The trial court denied a motion to set aside the verdict as not being warranted by the evidence and imposed the death sentence. The New York Court of Appeals affirmed, without opinion. ${ }^{103}$

The Supreme Court, confronted with the jury's uninformative general verdict of guilty, enumerated several possible courses of action which the jury, assuming that all of the jurors had acted on the same basis, might have taken with respect to the issue of voluntariness: (1) the jury had found the confessions voluntary and had used them as a basis for conviction; (2) the jury had found them involuntary and, in accordance with its instructions, had disregarded them and had based their verdict of guilt on the other evidence; (3) the jury had not adjudicated the voluntariness issue but had returned "an unanalytical and impressionistic verdict based on all they had heard."104 These three possibilities are not, of course, exhaustive. The jury might, for example, have found the confessions involuntary but might have been unwilling or unable to prevent them from entering into the verdict. Furthermore, as the Court explicitly recognized, the jurors may not have acted as a unit: “... we cannot know that some jurors may not have acted upon one basis, while some convicted on the other." 105

The Court was unwilling to invalidate the New York procedure merely because it created uncertainty regarding the jury's disposition, if any, of the voluntariness issue. Accordingly, it considered that its task was "to review hypothetical alternatives."106 Nevertheless, it did not review all of the possibilities which it had mentioned but only the first and second. It selected these for consideration, not because of any judgment regarding their greater probability, but apparently because they were the only alternatives open to the jury if it obeyed the trial court's instructions.

Such a review, although an interesting analytical exercise, is dominated by such a questionable presumption of jury-regularity that it does not come to grips with all of the constitutional difficulties raised by the New York procedure. Nevertheless, it is useful to examine the Court's point-bypoint analysis, with a view to marking out the reach of the Court's decision and appraising the dissenters' charge that the Court's action overturned settled constitutional doctrine.

The Court's first "hypothetical alternative," viz., a jury determination

${ }^{103}$ People v. Cooper, 303 N.Y. 856, 104 N.E. 2d 917 (1952).

104346 U.S. 156, 177 (1953).

${ }^{105}$ Ibid., at, 170 .

${ }^{108}$ Ibid.,_at 177. 
that the confession was voluntary, may appear, at first glance, to be easy to square with the Fourteenth Amendment. Such a determination by the jury would, the Court had previously found, have met the requirements of the Fourteenth Amendment. This finding by the Court would dispose of the constitutional question under the first alternative, except for one troublesome consideration. The jury would have made the voluntariness determination in the light of all the evidence and not merely the evidence surrounding the making of the confession. There was nothing in the judge's instructions which called upon the jury to exclude the evidence on the merits, apart from the confession, in resolving the voluntariness issue. Indeed, the Court itself recognized in the Stein case ${ }^{107}$ that the credibility of a confession "might bear" on its voluntariness, and its credibility is, of course, enhanced if it is consistent with the other evidence of guilt. Accordingly, it is probable that the other evidence of guilt was considered by the jury in resolving the conflict in the evidence concerning the voluntariness of the confession. But if this occurred, a problem arises under what appears to have been the Court's doctrine that a confession otherwise involuntary is not purified even though its reliability is shown by other evidence. ${ }^{108}$

Mr. Justice Frankfurter, in his dissent, underscored the need to separate the issue of voluntariness from that of guilt, stating: "This issue must be decided without regard to the confirmation of details in the confession by reliable other evidence. The determination must not be influenced by an irrelevant feeling of certitude that the accused is guilty of the crime to which he confessed." ${ }^{109}$ It is true that the Justice made this statement in the course of discussing Supreme Court determinations on review and not determinations at the trial stage. But there is no reason for applying different canons of relevancy at the trial and reviewing stage, respectively. Indeed, orderly review presupposes the applicability of the same canons at both stages. Furthermore, to permit a trial judge or jury to resolve doubts about voluntariness in the light of the other evidence of guilt appears to be inconsistent with the rationale for excluding involuntary confessions, previously announced by the Court. The Court has declared that confession doctrines are designed not merely to exclude untrustworthy evidence but also to deter oppressive police practices. ${ }^{110}$ To resolve doubts about voluntariness in the light of the other evidence of guilt is to divert attention

${ }^{107}$ Ibid., at 175.

${ }^{108}$ See Watts v. Indiana, 338 U.S. 49,50 n. 2 (1949).

${ }^{109} 346$ U.S. 156, 200 (1953).

${ }^{110}$ See page 348 supra. 
from the character of the relevant police conduct and is, therefore, to dilute the deterrent function of confession doctrines. In this connection, it is significant that Mr. Justice Jackson, who spoke for the Court in the Stein case had in an earlier dissenting opinion intimated that the confirmation of a confession by independent evidence is a factor to be considered by the Court in its review of a voluntariness determination. ${ }^{111} \mathrm{It}$ is also significant that the Court in the Stein case repudiated the deterrence rationale by declaring that the purpose of its confession doctrines is the exclusion of unreliable evidence. ${ }^{112}$

In dealing with the constitutionality of the second "hypothetical alternative," viz., that the jury had found the confessions involuntary and had disregarded them, the Court appeared to fuse two separable questions: (1) whether the defendants were entitled to a requested instruction that the jury should return a verdict of acquittal if they found the confession to be involuntary; and (2) whether the defendants were entitled to a reversal and a new trial if it were assumed that the jury had made such a finding. 'The defendants' request for the instruction was based on the doctrine previously announced by the Court: ${ }^{113}$ "If [a coerced confession] is introduced at the trial, the judgment of conviction will be set aside even though evidence apart from the confession might be sufficient to sustain the verdict." (It will be convenient to refer to this rule as "the rule of automatic reversal.")

'The defendants urged that without the requested instruction the jury would be permitted to return a verdict which, having been preceded by the introduction of an "involuntary confession," could not be allowed to stand. The Court, in the Stein case, appeared to be impressed by this argument, stating: ${ }^{114}$

If having heard an illegally obtained confession prevents a legal verdict of guilty on other sufficient evidence, why permit return of one foredoomed to be illegal? The alternative, of course, is an acquittal, which is what petitioner asked.

If this argument were accepted, it is clear that the doctrine of automatic reversal would pose a serious dilemma under the New York procedure. Either the trial court would be required to grant the requested instruction or the Supreme Court would be required to modify its doctrine. But the

III Watts v. Indiana, 338 U.S. 49, 57, 60 (1949). "[O]nce a confession is obtained, it supplies ways of verifying its trustworthiness. In these cases before us, the verification is sufficient to leave me in no doubt that the admissions of guilt were genuine and truthful."

112346 U.S. 156, 192 (1953). This shift in rationale is discussed page 347 infra.

${ }^{113}$ See Malinski v. New York, 324 U.S. 401, 404 (1945), and additional cases cited by the Court in the Stein case, 346 U.S. 156, 189 (1953).

114346 U.S. 156, 189. 
instruction, if it were followed by the jury, would have the far-reaching result of completely immunizing the defendant whenever the jury, assuming that it obeyed its instructions, found that his confession was involuntary, regardless of the strength of the other evidence of guilt. His acquittal would follow, and, under generally prevailing $c$ suble jeopardy doctrines, he would be protected against a subsequent trial on the same charge.

The Court concluded that the Fourteenth Amendment did not require the requested instruction to be given, at least where the evidence, apart from the challenged confession, was sufficient to sustain a verdict of guilt. ${ }^{115}$ But it was not entirely clear from the Court's discussion whether it was repudiating the doctrine of automatic reversal or only delineating more sharply the situations in which the doctrine had previously been applied.

No repudiation was necessary in order to justify the conclusion that the denial of the requested instruction was not a violation of the Fourteenth Amendment. Indeed, the Court in the Stein case at one stage, seemed explicitly to recognize this. The Court emphasized that its earlier cases had merely indicated that the defendant's conviction should be reversed when his confession had been found to be coerced. These cases had not suggested that the finding of coercion should result in immunity. ${ }^{116}$ Indeed, the Court had never in any context indicated that the use of unconstitutionally acquired evidence should as a matter of law produce immunity.

In addition, the Court recognized that the instruction would have been inconsistent with the assumption underlying the Court's second hypothetical alternative, viz., that the jury can and will dispose of the voluntariness issue and can and will exclude from its individual and collective deliberations any confession which it finds to be involuntary. ${ }^{117}$ This assumption is necessarily entertained by any jurisdiction which emf.nys the New York procedure. For a trial court in such a jurisdiction to grve the requested instruction when the evidence, apart from the confession, warrants a verdict of guilty would not only be to deny the underlying assump-

"125 Where the evidence, apart from the confession, is not sufficient to warrant a verdict of guilt, New York courts have instructed the jury to bring in a verdict of acquittal if it finds the confession involuntary. See People v. Leyra, 304 N.Y. 468, 108 N.E. $2 d 673$ (1952).

116346 U.S. 156 (1953).

117" [W] do not think our cases establish that to submit a confession to a state jury for judgment of the coercion issue automatically disqualified it from finding a conviction on other sufficient evidence, if it rejects the confession." Ibid., at 190. "By petitioners' hypothesis on this point, the jury itself rejected the confession. The ample other evidence makes this a possible, if not very convincing, explanation of the verdict. By the very assumption, however, there has been no error, for the confession finally was rejected as the free choice of the jury (sic)." Ibid., at 192. 
tion, but also would be tantamount to denying the constitutionality of the established method of resolving the voluntariness issue. ${ }^{118}$ Once the assumption behind the New York procedure is accepted, the jury's disregard of the confession is, moreover, no different from exclusion of the confession by the trial court. In either case, the involuntary confession is (it is assumed) not considered by the jury in arriving at its verdict. In either case, no approval is given by the legal system to the use of coerced confessions in arriving at a verdict.

The assumption made in connection with the second hypothetical alternative, that the jury would disregard a confession it found to be involuntary, operated not only to permit the denial of the instruction by the trial court but also to justify the Supreme Court's refusal to reverse. As we have seen, once it is assumed that the jury rejected the confession and excluded it from its deliberations, the case can be treated as if the trial court had excluded the confession. Accordingly, it seems clear that, given the underlying assumptions, the Court's disposition of the problems presented under the second alternative involved no conflict with its previous formulation of the rule of automatic reversal. ${ }^{119}$

Some of the Court's language, moreover, seemed to be designed to negate such a conflict. Thus it declared:120

We would have a different question if the procedure had been that which may have been in mind when some of our cases were written. Of course, where the judge makes a final determination that a confession is admissible and sends it to the jury as a part of the evidence to be considered on the issue of guilt and the ruling admitting the confession is found on review to be erroneous, the conviction, at least normally should fall with the confession. (Emphasis added.)

This statement appears to preserve the rule of automatic reversal in cases in which the orthodox procedure is employed to resolve the voluntariness issue, although the italicized phrase may be a source of uncertainty and controversy. The Court earlier in its opinion in the Stein case had also

${ }^{118}$ The New York procedure would presumably be abandoned if a finding of involuntariness by the jury would in effect immunize the defendant even though the evidence, apart from thes confession, warranted a verdict of guilt.

${ }^{\text {ug }}$ In Giron v. Cranor, 116 F. Supp. 92 (E.D. Wash., 1953), reported after this paper had been written, Driver, $J$., interpreted the Stein case as not overruling the rule of automatic reversal. Accordingly, in a habeas corpus proceeding he voided a state conviction on the ground that an involuntary confession had been admitted, even though he found that the other evidence justified a conviction. Whether the court's hearing de novo on the voluntariness issue in the Giron case was consistent with the standards suggested by Brown v. Allen, 344 U.S. 443, 506, 507, 546, 548 (1953), is, of course, a separate question which need not be pursued here.

120346 U.S. $156,192-93$ (1953). 
made it clear that the rule survived in cases employing the New York procedure where an assumed finding of voluntariness would have violated the Fourteenth Amendment. It had done this by holding that a prerequisite of its affirmance in the Stein case was its finding that a determination of voluntariness would not have violated the Fourteenth Amendment. ${ }^{121}$ Finally, there is no reason for dispensing with this requirement where the Massachusetts procedure is followed.

It should be noted that prior to the Stein case, the Court had indicated only that the rule of automatic reversal would be applied in situations where the Court concluded that the only permissible finding was one of involuntariness. To apply that rule in situations where a finding of voluntariness would have been permissible under the Fourteenth Amendment would, it is arguable, in effect impose higher standards of due process on a state merely because it had employed the New York procedure. For, although the trial judge's determination of voluntariness would not have been disturbed, the conviction would nevertheless fall because the jury, applying more rigorous standards than those imposed by the Court under the Fourteenth Amendment, might have held the confession to be involuntary.

Despite the Court's apparent attempt to guard the rule of automatic reversal, it went on to use language which cast doubt not only on that rule but also on the rationale underlying all of the Court's confession doctrines. The Court obliquely challenged the rule by indicating it was based on dicta, ${ }^{122}$ although it equivocated somewhat by recognizing that the rule had been applied in the Malinski case. ${ }^{23}$ In addition, it concluded its treatment of the second possibility (a jury finding of involuntariness) with a statement which rendered doubtful its previous acceptance of the rule of automatic reversal even where a determination of voluntariness would have been inconsistent with the Fourteenth Amendment:

We could hold that such provisional and contingent presentation of the confessions precludes a verdict on the other sufficient evidence after they are rejected only if we deemed the Fourteenth Amendment to enact a rigid exclusionary rule of evidence ralher than a guarantee against conviction on inherently untrustworthy evidence. ${ }^{124}$ We have refused to hold it to enact an exclusionary rule in the case of other illegally obtained evidence. Wolf v. Colorado, 338 U.S. 25; . . Coerced confessions are not more stained with illegality than other evidence obtained in violation of law. But re-

121 Ibid., at 188.

12 Ibid., at 189.

${ }^{123}$ Malinski v. New York, 324 U.S. 401 (1945).

${ }^{124}$ But cf. Jackson, J., dissenting in Ashcraft v. Tennessee, 322 U.S. 143, 159 (1944). ["Forced Confessions"] are ruled out because they have been wrung from a prisoner by measures which are offensive to concepts of fundamental fairness. 
liance on a coerced confession vitiates a conviction because such a confession combines the persuasiveness of apparent conclusiveness with what judicial experience shows to be illusory and deceptive evidence. A forced confession is a false foundation for any conviction, while evidence obtained by illegal search and seizure, wire tapping, or larceny may be and often is of the utmost verity. Such police lawlessness therefore may not void state convictions while forced confessions will do so. (Emphasis added.) ${ }^{125}$

The far-reaching implications of this passage reinforce the Court's delicate impeachment of the rule of automatic reversal as dicta. If the Fourteenth Amendment is a guarantee only against conviction on inherently untrustworthy evidence, why reverse when, with the-involuntary confession aside, there is ample trustworthy evidence to support the conviction? Why not indeed recognize, as some state courts had, ${ }^{126}$ that independent evidence derived from, and corroborating, the coerced confession, renders it trustworthy and admissible?

The Court's suggestion that coerced confessions were excluded under the Fourteenth Amendment only because of their untrustworthiness involved a basic shift in the Court's confession rationale. Previously, the Court had indicated that confession doctrines were designed in part as a deterrent against police misconduct, which is difficult to prove, which creates opportunities for physical violence and threats, and which is destructive of "an accusatorial system." Perhaps the clearest statement of the deterrent role of the Court's confession doctrines is contained in the Rochin case, ${ }^{128}$ where Mr. Justice Frankfurter, speaking for the Court, declared:

It has long since ceased to be true that due process of law is heedless of the means by which otherwise relevant and credible evidence is obtained. This was not true even before the series of recent cases enforced the constitutional principle that the States may not base convictions upon confessions, however much verified, obtained by coercion. ${ }^{129}$

\section{And again:}

Use of involuntary verbal confessions in State criminal trials is constitutionally obnoxious not only because of their unreliability. They are inadmissible under the Due Process Clause even though statements contained in them may be independently established as true. ${ }^{130}$

Although the Rochin case had been decided after Wolf v. Colorado, ${ }^{131}$ the Court in the Stein case pointed to the Wolf case as evidence that it "[had not] deemed the Fourteenth Amendment to enact a rigid exclusionary

${ }^{125} 346$ U.S. 156, 192 (1953).

${ }^{125}$ See 3 Wigmore, Evidence $\$ \S 856-58$ (3d ed., 1940).

${ }^{127}$ See note 52 supra.

129 Ibid., at 172-73.

${ }^{128}$ Rochin v. California, 342 U.S. 165 (1952).

${ }^{130}$ Tbid., at 173.

13338 U.S. 25 (1949). 
rule of evidence rather than a guarantee against conviction on inherently untrustworthy evidence." 32

It was odd for the Court to look to the $W$ olf case for the rationale behind its confession doctrines. That case clearly did not involve, and the Court's opinion did not mention, the Fourteenth Amendment's ban against coerced confessions. The Wolf case involved the question of whether the Fourteenth Amendment also barred the reception by a state court of evidence obtained in the course of an unreasonable search and seizure. It is true that the Wolf case means that the Fourteenth Amendment does not automatically require the exclusion of all evidence acquired by methods which violate that amendment. But it is also true that the Wolf case does not contain even a whisper that the Fourteenth Amendment will permit the reception of reliable evidence no matter how it is acquired.

Despite the difficulties of a double standard with respect to unconstitutionally extracted confessions and unconstitutionally seized evidence, respectively, there is justification for greater restrictions by way of the Fourteenth Amendment on the use of involuntary confessions. The principal justification is that unreasonable searches and seizures generally do not involve the same danger to the physical and psychological well-being of the suspect as does the brutality of the third degree. In this connection, it is significant that the Rochin case is distinguishable from Wolf $v$. Colorado only because it involved the same kind of threats to personality which are associated with coerced confessions. ${ }^{133}$

132346 U.S. 156, 192 (1953).

${ }^{133}$ Three policemen suspecting Rochin of illegal narcotics sales broke into his bedroom where they found him sitting partly dressed on the side of a bed on which his wife was lying. They also saw some capsules on a table beside the bed. The police, although they used force, failed in their attempt to prevent Rochin from swallowing the capsules. They took him to the hospital and forced him to submit to stomach pumping, which produced capsules containing morphine. These capsules were introduced into evidence in a state trial which resulted in Rochin's conviction. The Supreme Court reversed Rochin's conviction on the ground that the conduct of the police "shocks the conscience" (ibid., at 172), and, consequently, that the admission of the capsules violated the Fourteenth Amendment.

It is not clear from the Court's opinion, by Mr. Justice Frankfurter, whether stamach pumping alone without the added elements of illegal entry and the struggle to prevent the swallowing of the capsules, would have rendered the reception of the capsules into evidence unconstitutional. But his approach was sufficiently elastic to compel exclusion, under the Fourteenth Amendment, of evidence acquired by means which "shock the conscience," even though they do not involve force against the suspect's person.

Mr. Justice Black and Mr. Justice Douglas concurred in result but urged that the decision should have been based on the self-incrimination clause of the Fif th Amendment read into the Fourteenth Amendment and not on the "evanescent standards" of the majority. Black, J., ibid., at 177, see also Douglas, J., ibid., at 179. Query: Does the self-incrimination approach in determining the admissibility of different kinds af non-testimonial evidence, e.g., fingerprints and stomach contents, avoid "evanescent standards"? 
We have seen that the Court's underlying assumptions about jury-regularity avoided any conflict between affirmance in the Stein case and the rule of automatic reversal. Perhaps the Court's unnecessary questioning of that rule was prompted by its awareness, which it made explicit, of the unreality of its assumptions. Two other assumptions seem at least equally realistic and therefore must be considered: (1) the jury even if it made a finding of involuntariness did not disregard the confession in arriving at its verdict; (2) the jury made no finding but brought in a verdict based on all that it had heard. The statement of these assumptions is simply another way of defining the fresh problem involved, raised, and decided in the Stein case, namely, the constitutionality of the method of submitting the voluntariness issue under the New York procedure. This problem will now be examined on the basis of these "realistic" assumptions.

If the jury determined that a confession was involuntary but considered it and returned a verdict of guilty, the collision between affirmance by the Court and the rule of automatic reversal cannot, as under the Court's second hypothesis, be avoided by assumptions about jury regularity. The only way of avoiding that collision is to restate the rule of automatic reversal so that it applies only when a reviewing court holds that a finding of involuntariness was made mandatory by the Fourteenth Amendment. But this restatement appears to be unsatisfactory. If a judge had made a finding of involuntariness which was reasonable but not inescapable, but nevertheless had admitted the confession, the rule of automatic reversal would presumably have been applied to void the conviction-at least prior to Stein. ${ }^{134}$ Presumably, the same result would follow if, to take an

${ }^{134}$ Cf. Stroble v. California, 343 U.S. 181, 190 (1952), where the Court, in reversing the "assumption" of the California Supreme Court that the first of several confessions was involuntary, found that even though all factual questions were resolved in the defendant's favor, it could not fairly be said that the first confession was involuntary.

Frankfurter, J., in his dissent, suggested that "if a State court, reading the record in the light of its intimate knowledge of local police and prosecutorial methods should conclude that a confession was coerced, I cannot believe that this Court would set aside that appraisal and decide independently that the confession was wholly free. ..." Ibid., at 203.

With respect to Mr. Justice Frankfurter's point, it seems useful to distinguish between questions of "fact," i.e., what happened to this defendant, and questions going to the content and applicability of federal constitutional standards. Where a state appellate court has reversed a finding of voluntariness because of an erroneous belief as to the standards imposed by the Fourteenth Amendment, e.g., a mistaken belief that the McNabb rule is binding on the states, it is dificult to see why the Supreme Court should refuse to review and to reverse. Cf. in this connection United States v. Carignan, 342 U.S. 36 (1951), discussed page 333 supra, where the court, although reversing a conviction, rejected the determination by the Ninth Circuit Court of Appeals that a confession had been received in violation of the McNabb doctrine. Although Mrr. Justice Douglas, with whom Mr. Justice Black and Mr. Justice Frankfurter concurred, did not join the Court on this point, the concurring opinion did not suggest that it was improper for the Court to reverse a holding by a court of appeals that a confession should not have been admitted. 
unlikely case, the jury had made the same finding but had indicated in a special verdict that it had taken the confession into account in arriving at a verdict of guilt.

The Court did not explicitly deal with the problems raised by the possibility that the jury found the confession to be involuntary but nevertheless considered it. The Court did, however, mention the possibility that the jury made no determination on the voluntariness issue but based its verdict on all that it had heard. The Court dismissed this possibility as an inseparable element of jury trial on more than one issue. Although at one juncture the Court disclaimed any judgment regarding the wisdom of the New York procedure, ${ }^{135}$ later on it referred to that procedure as "a traditional practice assumed on the whole to be of advantage to the defense and an additional protection to the accused." 136 The assumption that the New York procedure helps the defendant ignores the difficulties, discussed earlier in this paper, which that procedure creates for the defendant. In any event, it is necessary to pursue the implications of the Court's suggestion that the jury failed to make any determination of the voluntariness issue.

In other contexts, the Court has held that the Fourteenth Amendment entitles a party to an independent judicial judgment on issues of constitutional fact. ${ }^{137}$ The learned in these matters say that the doctrine of constitutional fact has lost its vitality. ${ }^{138}$ But a sliver of that doctrine may still survive or at least deserves to survive. A defendant in a criminal trial should at the trial stage be entitled to a clean-cut adjudication as to whether he has been deprived of rights conferred by the federal Constitution. The New York procedure clearly does not provide for such an adjudication. Under that procedure the judge does not resolve the voluntariness issue, the jury theoretically is supposed to but may not resolve that issue. And even if the jury does determine that issue in favor of the defendant, it is likely that the jury cannot achieve the purpose behind its determination-the insulation of its deliberations against a confession which it has heard.

The appellate courts when they act often are not required to make an independent finding but may determine only whether a determination adverse to the defendant was a permissible resolution of thorny questions of

135346 U.S. 156, 179 (1953).

${ }^{136} \mathrm{Tbid}$. , at 189. (Emphasis added.)

${ }^{137}$ See Hart, The Power of Congress to Limit the Jurisdiction of Federal Courts, 66 Harv. L. Rev. 1362, 1376-77 (1953).

${ }^{338}$ Ibid. 
fact. They may make this limited determination, moreover, against a tradition which may give the assumed jury finding a greater invulnerability to reversal than the actual finding of a court. ${ }^{139}$

It is true, as the Court indicated in the Stein case, that uncertainty as to the jury disposition is inherent in any jury trial of two or more issues. But this consideration does not dispose of the special difficulties in the confession cases resulting from the fact that it is a constitutional issue which is not, or may not be, adjudicated.

It may be urged that the use of the Fourteenth Amendment to insure the adjudication of issues on which the constitutionality of receiving particular items of evidence depends might involve a far-reaching disturbance of state patterns of judge-jury allocation. The extent to which this might occur would depend largely on whether the Court would read the hearsay rules into the Fourteenth Amendment-a problem which divided the Court in the Stein case. ${ }^{140}$ That problem need not be pursued here. The answer to the objection to disturbing local procedural patterns may appropriately be one of confession and avoidance. If a question of admissibility coincides with a federal constitutional question, it seems appropriate for the Supreme Court to insist that local procedures provide for a clean-cut adjudication of that question. When the question turns on disputed issues of fact, it also seems appropriate to require that those issues be squarely adjudicated on the basis of all of the competent evidençe elicited at the trial stage.

In summary, the Court's analysis does not meet the constitutional difficulties raised by the New York rule as to judge-jury allocation. Its first hypothetical alternative, a determination of voluntariness by the jury, involves the risk that this determination will be influenced, if not dominated, by the other evidence of guilt. Its second alternative, a determination of involuntariness and disregard of the confession by the jury, does not involve any difficulty once the assumption of jury regularity is accepted. But in the confession context this assumption is reminiscent of the difficulty with fictions which Mr. Justice Jackson recently noticed: "[T]hose they are most apt to mislead are those who proclaim them."141 If the assumption of jury regularity is not made, the New York procedure involves the possibility that the jury convicts on the basis of either a confession which it found involuntary or a confession the voluntariness of

${ }^{139}$ See Stern, Review of Findings of Administrators, Judges and Juries, 58 Harv. L. Rev. 70, esp. 88-89 (1944); cf. McCormick, op. cit. supra note 5, at 261.

${ }^{140}$ See note 10 supra.

${ }^{141}$ Jackson, J., concurring in Brown v. Allen, 344 U.S. 443, 532, 542 (1953). 
which it did not adjudicate. It is difficult to square a procedure which involves such possibilities with the requirements of the Fourteenth Amendment.

Turning from the Court's argument to speculation about the possible effect of its opinion on police abuses, we are confronted with the disturbing charge in Mr. Justice Frankfurter's dissent: ${ }^{142}$

It is painful to be compelled to say that the Court is taking a retrogressive step in the administration of criminal justice. I can only hope that it is a temporary, perhaps an $a d$ hoc, deviation from a long course of decisions. By its change of direction the Court affords new inducement to police and prosecutors to employ the third degrees whose use the Wickersham Commission found "widespread" more than thirty ycars ago and which it unsparingly condemned as "conduct ... violative of the fundamental principles of constitutional liberty."

Mr. Justice Frankfurter, like his colleagues in dissent, did not clearly indicate whether this charge was based on the Court's holding or its language. And yet, the merits of his charge are crucially dependent on whether the Court's decision or its dictum is emphasized. The Court's decision, which did no more than sustain the constitutionality of the New York procedure for resolving the voluntariness issue, does not support the Justice's charge. Given the Court's underlying assumptions about jury-regularity, which were not even mentioned by the dissenters, the Court's decision did not involve a repudiation of the rule of automatic reversal. ${ }^{143}$ Accordingly, it is difficult to see how the decision affords new inducements to the use of the third degree. All that the decision suggests to the prosecution is a gamble on the use of a confession where a finding either way on the voluntariness issue would be permissible. The inducement to gamble on the possibility that a doubtful confession might pass judicial scrutiny existed long before the Stein case, under the New York procedure as well as the alternative procedures for resolving the voluntariness issue. ${ }^{144}$

The Court's intimation that the Fourteenth Amendment is a guaranty only against conviction on inherently untrustworthy evidence is, of course, a different story. ${ }^{145}$ If the implications of this intimation were fol-

142346 U.S. 156, 201 (1953).

${ }^{143}$ See page 346 supra.

114 In connection with inducements to secure coerced confessions, it should be noted that the Court has not yet held that the Fourteenth or the Fifth Amendment bars the reception of fruits of an involuntary confession. Cf. Comment, 17 Univ. Chi. L. Rev. 706, 715-16 (1950). Indeed, the Court has implied that the fruits of a confession secured in violation of the McNabb rule are admissible in a federal criminal trial. See United States v. Bayer, 331 U.S. 532, 539-41 (1947). So long as the fruits of an illegal confession are admissible, there is a powerful inducement to the police to use the third degree.

${ }^{145}$ See page 347 supra. 
lowed, which seems unlikely, ${ }^{146}$ the rule of automatic reversal would be abandoned. Under such circumstances the problem for the prosecution concerned about reversal would not be to avoid the use of coerced confessions but only to insure their verification by independent evidence. The prosecution might then be encouraged to supplement other evidence by introducing a coerced confession in order to guarantee a conviction. On review, it could defend the conviction on the ground that it was warranted by the independent evidence.

The failure of the dissenters to distinguish between what the Court decided and what the Court said may produce results which would be paradoxical in the light of the values which generated the dissents. The dissenters eloquently voiced the importance of protecting suspects and our society against the brutalizing effects of the third degree. And yet, if inferior courts should accept the dissenting opinions as statements of the Court's holding, they would conclude that the rule of automatic reversal had been repudiated by the Stein case. If this should occur, the dissenters in the short run at least would have encouraged the very evils which they so eloquently condemned.

The Court's opinion, which stressed the interest of the state in apprehending and convicting the guilty, may also have paradoxical consequences. By focussing on the weaknesses of the New York procedure, the Court may stimulate the abandonment of that procedure. In that way, the Court, despite its emphasis on the state's interest, may enhance the protection accorded to defendants against the admission of coerced confessions.

146 If these implications were followed, the Court would be required to repudiate the Rochin case (see page 349 supra), its own language in the Stein case which preserved the rule of automatic reversal, and a whole line of confession cases. See note 52 supra. 